\title{
Are corridors, fragment size and forest structure important for the conservation of leaf-litter lizards in a fragmented landscape?
}

\author{
Marianna Dixo and Jean Paul Metzger
}

\begin{abstract}
To investigate the implications of forest fragmentation for conservation of leaf-litter lizards the importance of fragment size, corridors and forest structure was examined in 20 forest fragments and six localities within a continuous forest in the Atlantic Plateau of São Paulo state, Brazil. The fragments were $2-276$ ha in area and had different degrees of connectivity depending on the presence or absence of corridors. Two species of lizards were dominant, Ecpleopus gaudichaudii and Enyalius perditus. Variation in forest structure among sites was important only in explaining the abundance of E. perditus. Regardless of variation in forest structure, lizard species composition, total lizard abundance, number of species and abundance of E. perditus were sensitive to fragmentation per se but not to fragment size or corridor linkage. The inhospitable matrix surrounding fragments is probably what determines the presence and abundance of E. perditus and the higher lizard richness in continuous forests. These conditions may have prevented lizard species from recolonizing the forest fragments. Our results emphasize that the conservation of this leaf-litter fauna depends on the maintenance of large tracts of continuous forests and not on the size of fragments or on the presence of forest connections. Strategies for conservation of leaf-litter lizards in such highly fragmented Atlantic Forest landscapes should consider the enlargement of landscape connectivity between fragments and continuous forest, allowing the latter areas to act as a source of individuals for fragments.
\end{abstract}

Keywords Atlantic rainforest, Brazil, connectivity, fragmentation, forest structure, leaf-litter lizards.

\section{Introduction}

T abitat loss and fragmentation are considered the 1 major causes of species extinction and biodiversity loss (Fahrig, 2003). Despite the growing number of studies on the effects of these processes on various organisms, amphibians and reptiles are amongst the least studied groups, together representing only $4 \%$ of articles pub-

Marianna Dixo (Corresponding author) and Jean Paul Metzger Department of Ecology, Institute of Bioscience, University of São Paulo, Rua do Matão, 321, travessa 14, 05508-900, São Paulo, SP, Brazil. E-mail mariannadixo@yahoo.com.br

Received 28 August 2007. Revision requested 29 September 2007. Accepted 7 January 2008. lished in 1995-2000 in some of the major ecology journals (McGarigal \& Cushman, 2002). However, habitat loss and fragmentation can contribute to population declines of reptiles (Gibbons et al., 2000; Araújo et al., 2006) and, as a consequence, may affect other species through trophic interactions (Brown \& Nelson, 1993; Rodrigues, 2005; Whitfield \& Donnelly, 2006).

Reptiles have characteristics such as small home ranges and low energetic requirements (Pough et al., 1998) that may allow them to maintain viable populations even in small habitat fragments (McGarigal \& Cushman, 2002) and are therefore presumed to be less vulnerable to habitat loss and fragmentation than small mammals and birds (Dickman, 1987; McGarigal \& Cushman, 2002), despite some evidence of their sensitivity (Sarre et al., 1995; Smith et al., 1996; Cosson et al., 1999; Driscol, 2004; Bell \& Donnelly, 2006). Some studies have shown that habitat structure may be more important for reptiles than the size of a fragment (Kichener et al., 1980; Jellinek et al., 2004). There is currently no consensus about the relative influence of isolation, connectivity or presence of corridors on lizard communities (Smith et al., 1996; Burbrink et al., 1998; Maisonneuve \& Rioux, 2001; Driscol, 2004; Bell \& Donnelly, 2006).

Most studies of the effects of habitat loss and fragmentation on lizards have been in Australia (Kichener et al., 1980; Sarre et al., 1995; Smith et al., 1996; Sumner et al., 1999; Driscol, 2004; Jellinek et al., 2004), with only a few in the neotropics (Dixo, 2001, 2005; Freire, 2001; Silvano et al., 2003; Bell \& Donnelly, 2006). In the Atlantic Forest of South America, one of the global biodiversity hotspots (Myers et al., 2000), now reduced to $<12 \%$ of its original extent (SOS Mata Atlântica/INPE, 2008; Ribeiro et al., 2009), little is known about the effect of fragmentation on lizards (Dixo, 2001; Freire, 2001; Silvano et al., 2003; Dixo \& Martins, 2008). In a study carried out in Bahia, north-east Brazil, no differences were found in reptile species richness, abundance and diversity between small (25100 ha) and large ( $>$ 1,00o ha) fragments (Dixo, 2001; Pardini et al., 2009). However, this study was in a landscape with high connectivity, where fragments are located in a landscape with $49 \%$ forest cover surrounded by an inter-habitat matrix dominated by forest formations (secondary forests, shaded cacao and rubber plantations, covering $23 \%$ of the landscape). This forested matrix could represent secondary habitats for the majority of the species (Faria et al., 2007), thus contributing to the absence of a response to forest fragmentation (Dixo, 2001). 
In the study reported here we investigated the effect of habitat fragmentation per se (Fahrig, 2003), fragment size, corridor linkages and forest structure on the leaf-litter lizard community in an Atlantic Forest landscape with an old history of disturbance ( $>150$ years). The total forest cover is $31 \%$, predominantly surrounded by an agricultural matrix. We compared the number of species, total abundance, and abundance of two species of leaf-litter lizards in fragments and continuous forest to test the hypotheses that: (1) fragmentation negatively affects this lizard community, (2), large fragments and the presence of corridors reduce the effects of fragmentation, and (3) forest structure influences the lizard community. Our results are important for the design of strategies for the conservation of lizards in the Brazilian Atlantic forest.

\section{Study area}

The Atlantic Forest biome formerly occupied the whole Brazilian coast but is currently represented by a mosaic of sparse and isolated forest fragments, often severely damaged and $<50$ ha (Ribeiro el al., in press). Our study was on the Ibiúna Plateau, $40 \mathrm{~km}$ south-east of São Paulo, chosen because of the existence of a continuous forest and a fragmented landscape in similar conditions of relief, altitude, climate and forest succession. Altitudes are 870-1,030 m, climate is temperate hot and humid, type Cfa in the Köppen (1948) system, and mean maximum and minimum temperatures are 27 and $11^{\circ} \mathrm{C}$, respectively. Annual mean precipitation is c. $1,340 \mathrm{~mm}$ and varies seasonally, with colder and drier months in April-August. The original forest is classified as lower montane rainforest (Oliveira-Filho \& Fontes, 2000), with elements of Araucaria mixed forest and semi-deciduous forest (Catharino et al., 2006).

The continuous forest, the Morro Grande Forest Reserve, of c. 9,400 ha, is connected to one of the largest Atlantic Forest remnants, on the slopes of the Paranapiacaba mountain range $(>760,000 \mathrm{ha})$. The reserve is composed of a mosaic of secondary forests (sensu Brown \& Lugo, 1990) in different stages of succession, most with $60-80$ years of regeneration, and others that are older and well structured (Metzger et al., 2006). The fragmented landscape is adjacent to the Reserve (Fig. 1) and is relatively heterogeneous, with a predominance of forests at an intermediate to advanced stage of succession (31\%). Vegetation in early stages of succession and open areas (agriculture and pasture, including fallow lands and areas in early plant succession) covers an additional $43 \%$ of the landscape, reforested areas $7 \%$, aquatic areas $3 \%$, and built up areas (rural and urban) a further $16 \%$ (Seabra, 1971).

\section{Methods}

We sampled leaf-litter lizards in 20 forest fragments and in six areas within the Morro Grande Forest Reserve. Frag- ments were selected to represent the range of fragment size and connectivity in the studied landscape (Table 1). Assessment of connectivity (connected or isolated) was based on the presence or absence of corridors to large fragments. Corridors are of native vegetation, mainly of secondary forest, and 25-100 $\mathrm{m}$ wide. Within each size and connectivity class selection of fragments was random after fragments with high levels of human disturbance (e.g. presence of cattle, understorey clearing, selective logging) or structural alteration were excluded. Fragments were at an intermediate to advanced stage of succession (6o-80 years of regeneration; Teixeira et al., 2009). Mean distance between selected forest fragments was c. $1.4 \mathrm{~km}$. Within the Morro Grande Forest Reserve six sites in similar conditions of forest succession were selected, each at least $2.4 \mathrm{~km}$ apart. Fragment sizes were obtained from a detailed map produced from visual interpretation of 1:10,000 aerial photographs taken in April 2000 (Silva et al., 2007). Little alteration has occurred in the spatial distribution of the forests since 2000. The area of fragments was calculated with FRAGSTAT v. 3.3 (McGarigal \& Marks, 1995) using a raster image with a resolution of $10 \mathrm{~m}$.

Sampling of leaf-litter lizards was with pitfall traps (Corn, 1994; Cechin \& Martins, 2000). Captured lizards were marked and released individually. In each of the 26 sites 11 6o-litre buckets were installed in a line, with a $10 \mathrm{~m}$ fence-guide ( $50 \mathrm{~cm}$ high) between traps, resulting in a 100-m line. Trap lines were placed a minimum distance of $50 \mathrm{~m}$ from the fragment or forest edge, except in the small fragments where buckets were installed as far away from the edge as possible. Because our objective was to investigate spatial and not seasonal patterns, we sampled only during summer (the wet season), the time of year when lizard capture success is higher for pitfall traps (Dixo, 2005). Surveys were in January-February 2002 and December 2002-January 2003. In each period the buckets were open for 16 days, resulting in a total of 352 pitfall trap days per site and a total of 9,152 pitfall trap days.

\section{Forest structure}

We measured foliage density and stratification using an adaptation of the method described in Malcolm (1995; for more details see Pardini et al., 2005). Foliage density and stratification are good indicators of forest regeneration stages (De Walt et al., 2003) and level of forest disturbance (Malcolm \& Ray, 2000). At each site 12 stations spaced $15 \mathrm{~m}$ apart were set in each of two parallel lines of $165 \mathrm{~m}, 20 \mathrm{~m}$ apart, overlaying the pitfall trap line. The stature of the inferior and superior limits of all foliage along the imaginary column was measured and used to calculate the length occupied by foliage in five strata $(0-1,1-5,5-10,10-$ $15,>15 \mathrm{~m}$ ). For each site we calculated the mean foliage length in each stratum. 


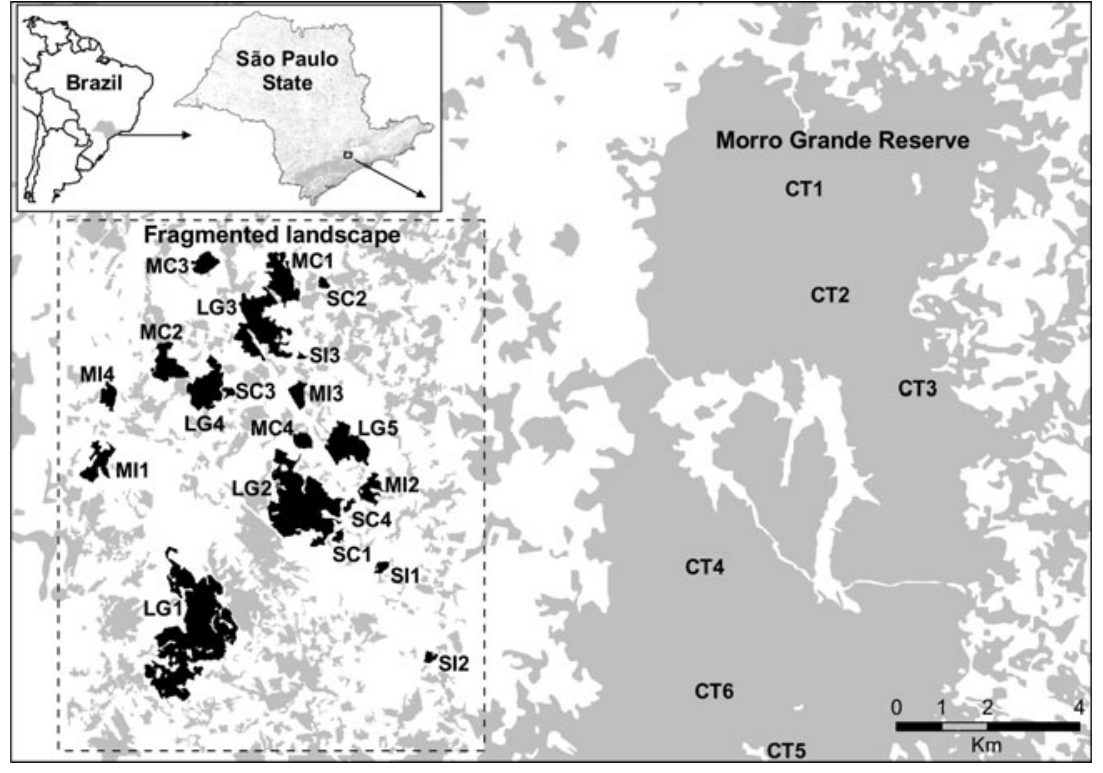

FIG. 1 The location of the studied fragmented landscape in the Ibiúna Plateau and the Morro Grande Reserve (abbreviations of the sites as in Table 1). The inset indicates the location of the study area in the state of São Paulo, Brazil.

\section{Data analysis}

To estimate lizard species richness and evaluate the completeness of our inventory we used a first-order jacknife estimator calculated with EstimateS (Colwell, 1997) to de-

TABLE 1 The size, connectivity and area of the 26 study sites on the Ibiúna Plateau (Fig. 1).

\begin{tabular}{lllr}
\hline Site & Size & Connectivity & Area (ha) \\
\hline CT1 & Continuous forest & & \\
CT2 & Continuous forest & & \\
CT3 & Continuous forest & & \\
CT4 & Continuous forest & & \\
CT5 & Continuous forest & & \\
CT6 & Continuous forest & & \\
LG1 & Large & & 274.34 \\
LG2 & Large & & 175.10 \\
LG3 & Large & & 99.39 \\
LG4 & Large & & 53.08 \\
LG5 & Large & & 52.17 \\
MC1 & Medium & Connected & 47.88 \\
MC2 & Medium & Connected & 31.22 \\
MI1 & Medium & Isolated & 28.88 \\
MI2 & Medium & Isolated & 18.78 \\
MC3 & Medium & Connected & 18.33 \\
MI3 & Medium & Isolated & 14.08 \\
MI4 & Medium & Isolated & 14.00 \\
MC4 & Medium & Connected & 12.92 \\
SI1 & Small & Isolated & 5.48 \\
SI2 & Small & Isolated & 4.98 \\
SC1 & Small & Connected & 4.75 \\
SC2 & Small & Connected & 4.57 \\
SC3 & Small & Connected & 3.81 \\
SC4 & Small & Connected & 3.63 \\
SI3 & Small & Isolated & 1.96 \\
\hline
\end{tabular}

${ }^{*}$ Continuous forest, areas of the Morro Grande Forest Reserve (c. 9,400 ha); Large, fragments of 50.1-276 ha; Medium, $10-50$ ha; Small, $<5.5$ ha termine the percentage of estimated richness that was actually observed. To describe forest structure a principal component analysis (PCA) was performed using the foliage density in the five strata in the 26 sites in a correlation matrix (centred and standardized per species) using CANOCO v. 4.0 (ter Braak \& Smilauer, 1998). To examine the influence of forest structure, species richness, total abundance and abundance of individual species were regressed against the 26 site scores of the first axis of the PCA.

To test the effects of forest fragmentation on the lizard community we compared the richness, total abundance and abundance of species of leaf-litter lizards between continuous forest and isolated fragments (small- and mediumsized) using the independent $t$-test. To test the effect of the presence of corridors we carried out a two-way ANOVA considering two classes of fragment size (small- and medium-sized) and the presence or absence of corridors. Barlett's test of homogeneity of variance was calculated and, where necessary, data were $\log$ transformed. All statistical analyses were performed with Statistica v. 6.1 (StatSoft, 2001). Simple linear regressions were used to test the relationship of species richness, total abundance and abundance of the two most common species of lizards with fragment area. To minimize the influence of forest structure differences among sites, ANOVAs, $t$-tests and simple regressions were carried out using the residuals from the regressions of lizard variables against the first axis of the PCA.

We used the non-parametric Multi-Response Permutations Procedure (MRPP; Zimmerman et al., 1985) to test differences in lizard composition caused by fragmentation (isolated fragments vs continuous forest), fragment size reduction (small, medium and large fragments), and among the connected and isolated fragments (small- and 
medium-sized). These analyses were performed with PC-ORD v. 4.1 (McCune \& Mefford, 1997).

\section{Results}

A total of 228 individuals of five species of leaf-litter lizards were captured, belonging to two families, Gymnophthalmidae and Leiosauridae (Table 2). The observed richness was equal to that estimated by the Jacknife procedure, indicating that we achieved a complete inventory of the leaflitter lizard assemblage. The number of species per fragment was 0-4 (Table 2). Ecpleopus gaudichaudii and Enyalius perditus were the commonest species (95\% of the total abundance).

The first axis of the PCA explained $43.5 \%$ of the total variation in forest structure among the 26 sites. It represents a gradient of increasing foliage density in the lower strata and decreasing density in the higher strata. Number of lizard species, total abundance and abundance of $E$. gaudichaudii were not significantly related to the gradient of forest structure $\left(R^{2}=0.008, \mathrm{P}=0.283 ; R^{2}=0.000, \mathrm{P}=0.511\right.$; $R^{2}<0.001, \mathrm{P}=0.721$, respectively, Fig. 2). The abundance of $E$. perditus was significantly negatively correlated with the first axis of the PCA, decreasing towards forest in earlier stages of regeneration or subjected to higher levels of disturbance $\left(R^{2}=0.243, \mathrm{P}=0.006\right.$; Fig. 2$)$.

The continuous forest had more species and more individuals of leaf-litter lizards than fragments $(\mathrm{df}=11$, $t=-3.384, \mathrm{P}=0.006 ; \mathrm{df}=11, t=-3.184, \mathrm{P}=0.009$, respectively). E. perditus was more abundant in continuous forest than in fragments $(\mathrm{df}=11, t=-6.113, \mathrm{P}<0.001)$ but abundance of E. gaudichaudii did not vary between sites $(\mathrm{df}=11$, $t=-1.432, \mathrm{P}=1.798)$. The composition of the lizard community also varied significantly between continuous forest and fragments (MRPP: $\mathrm{n}=13, t=-2.718, \mathrm{P}=0.019$ ).

Richness $\left(\mathrm{n}=20, R^{2}=0.052, \mathrm{P}=0.170\right)$, total abundance ( $\left.\mathrm{n}=20, R^{2}=0.025, \mathrm{P}=0.239\right)$, abundance of E. gaudichaudii $\left(\mathrm{n}=20, R^{2}=0.003, \mathrm{P}=0.315\right)$, and abundance of
E. perditus $\left(\mathrm{n}=20, R^{2}=0.000, \mathrm{P}=0.787\right)$ were not correlated with $\log ($ area $)$. The composition of the lizard community did not vary significantly between small, medium and large fragments (MRPP: $\mathrm{n}=20, t=-0.206$, $\mathrm{P}=0.406$ ).

Species composition was not significantly different (MRPP: $\mathrm{n}=15, t=-1.025, \mathrm{P}=0.148$ ) nor were number of species, total abundance and the abundance of E. gaudichaudii significantly higher in connected than in isolated fragments, and did not differ between small and mediumsized fragments (Table 3 ). The abundance of $E$. perditus was not analysed because this species was not found in the connected fragments (Table 2).

\section{Discussion}

The main conclusion from this study is that, in a comparison of continuous and fragmented forest, the leaf-litter lizards of the Ibiúna Plateau are sensitive to fragmentation per se (Hypothesis 1 is thus not refuted) but not to fragment size or connection by corridors (refuting Hypothesis 2), and only one species (E. perditis) is sensitive to forest structure (Hypothesis 3 therefore holds true only for some species). Despite the low species richness of this leaf-litter lizard community the number of species is that expected for the region, and is similar to that of other Atlantic Rainforest sites, such as the Japi Mountain Range and Fazenda Intervales, each with five species (Sazima \& Haddad, 1992; Sazima, 2001). The number of species is slightly less than recorded at the Ecological Station Juréia-Itatins but this latter area is more heterogeneous in habitat types and structure and has a broader altitudinal gradient (Marques \& Sazima, 2004).

Variation in forest structure did not influence lizard species richness, total abundance or abundance of E. gaudichaudii. These results were not expected given that previous studies have found that habitat structure,

TABLE 2 Occurrence and abundance of the five species of leaf-litter lizards in the different classes of fragment size (small, medium or large) and connectivity (isolated or connected), and in the continuous forest (Table 1, Fig. 1).

\begin{tabular}{|c|c|c|c|c|c|c|c|}
\hline \multirow[b]{2}{*}{ Species (by Family) } & \multicolumn{2}{|l|}{ Small (n) } & \multicolumn{2}{|l|}{ Medium (n) } & \multirow{2}{*}{$\begin{array}{l}\text { Large } \\
(\mathrm{n}=5)\end{array}$} & \multirow{2}{*}{$\begin{array}{l}\text { Continuous } \\
\text { forest }(n=6)\end{array}$} & \multirow{2}{*}{$\begin{array}{l}\text { Total } \\
(n=26)\end{array}$} \\
\hline & Isolated (3) & Connected (4) & Isolated (4) & Connected (4) & & & \\
\hline \multicolumn{8}{|l|}{ Gymnophthalmidae } \\
\hline Colobodactylus taunayi & & & & 1 & & 1 & 2 \\
\hline Heterodactylus imbricatus & & & & 4 & & 2 & 6 \\
\hline Placosoma glabellum & & & 1 & 2 & 2 & & 5 \\
\hline $\begin{array}{l}\text { Ecpleopus gaudichaudii } \\
\text { Leiosauridae }\end{array}$ & 2 & 15 & 29 & 3 & 43 & 60 & 152 \\
\hline Enyalius perditus & 9 & & 3 & & 3 & 48 & 63 \\
\hline Total abundance & 11 & 15 & 33 & 10 & 48 & 111 & 228 \\
\hline Total no. of species & 2 & 1 & 3 & 4 & 3 & 4 & 5 \\
\hline
\end{tabular}



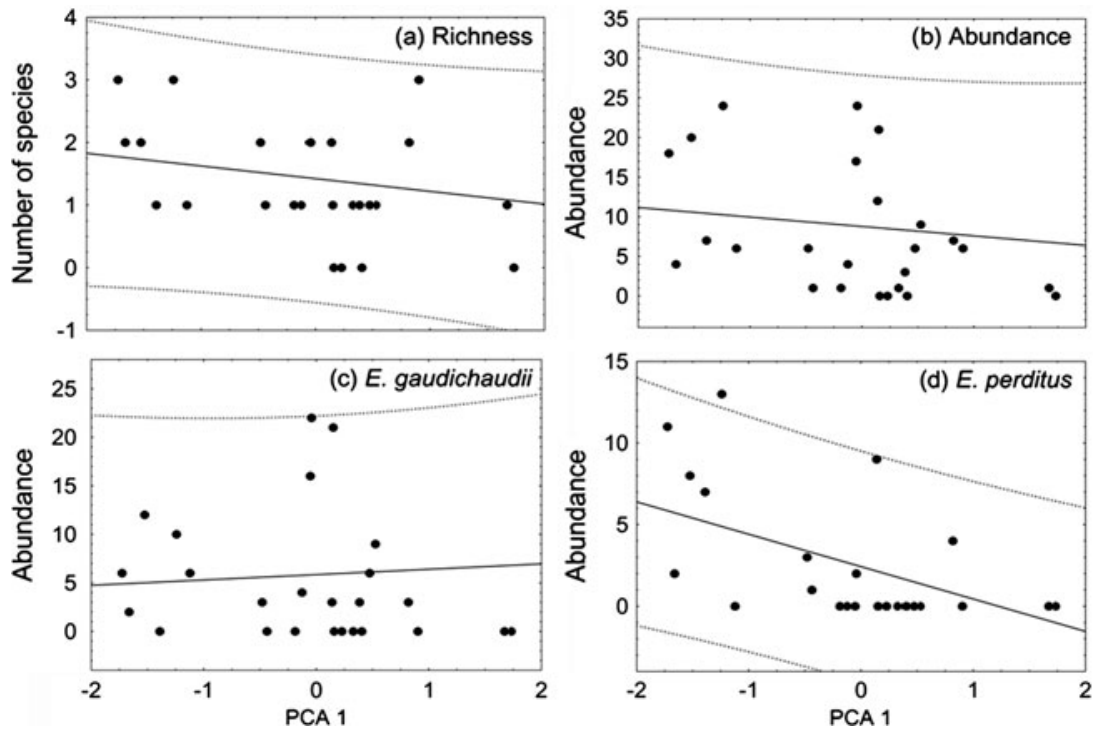

FIG. 2 Relationship of (a) lizard richness, (b) total abundance, (c) abundance of Ecpleopus gaudichaudii and (d) abundance of Enyalius perditus with forest structure in 26 sites (Fig. 1, Table 1), the latter summarized by scores on the first axis of a PCA of foliage density in five strata (see text for details). Forest in earlier stages of regeneration or subjected to higher levels of disturbance, with lower canopy and denser understorey, has higher scores on PCA axis 1. heterogeneity and vegetation complexity are essential for the maintenance of herpetofaunal diversity (Burbrink et al., 1998; Maisonneuve \& Rioux, 2001) and were, in some cases, more important than fragment size (Kichener et al., 1980; Jellinek et al., 2004). Our results suggest that the Gymnophthalmidae in Ibiúna, and particularly E. gaudichaudii, can live in secondary habitats as long as the leaf-litter stratum remains relatively undisturbed.

The only species in Ibiúna that appears to be sensitive to forest structure is E. perditus. This species was also sensitive to fragmentation and was more abundant in preserved and less disturbed areas. The genus is known to be restricted to closed-canopy forest (Jackson, 1978). The different microhabitats used by E. perditus and E. gaudichaudii may influence their responses to fragmentation and changes in forest structure. E. gaudichaudii appears to be dependent on leaf-litter, regardless of forest age, cover, area or canopy density and height (but may not tolerate silting, burning or removal of leaf-litter, even if the arboreal stratum is left undisturbed) whereas E. perditus seems to be more sensitive to logging and forest degradation.

However, fragment area had no influence on the abundance of E. perditus. As it is sensitive to forest structure but

TABLE 3 Two-way ANOVA comparing total lizard abundance, species richness and abundance of $E$. gaudichaudii between areas of different connectivity (presence/absence of corridors) and fragment size (small and medium-sized).

\begin{tabular}{|c|c|c|c|c|c|c|}
\hline & \multicolumn{2}{|c|}{ Abundance } & \multicolumn{2}{|c|}{ Richness } & \multicolumn{2}{|c|}{ E. gaudichaudit } \\
\hline & $\mathrm{F}_{(1,11)}$ & $\mathrm{P}$ & $\mathrm{F}_{(1,11)}$ & $\mathrm{P}$ & $\mathrm{F}_{(1,11)}$ & $\mathrm{P}$ \\
\hline Connectivity & 0.64 & 0.441 & 0.18 & 0.675 & 1.06 & 0.326 \\
\hline Fragment size & 1.11 & 0.315 & 2.74 & 0.125 & 0.49 & 0.500 \\
\hline $\begin{array}{l}\text { Connectivity } \times \\
\text { fragment size }\end{array}$ & 2.33 & 0.155 & 0.01 & 0.907 & 4.59 & 0.055 \\
\hline
\end{tabular}

can persist in small fragments, it probably has a small home range and low energetic requirements. Preliminary results from an ongoing study of E. perditus indicate that it is not a very active species and that its movements are greater in the vertical than the horizontal forest stratum (Liou, 2008).

Regardless of variation in forest structure, lizards were sensitive to fragmentation per se but not to fragment size or connectivity. This fragmentation effect is consistent with other studies (Sarre et al., 1995; Smith et al., 1996; Driscol, 2004; Bell \& Donnelly, 2006) but differs from findings in the north-east Atlantic Forest (Dixo, 2001; Silvano et al., 2003), where the landscape has a larger percentage of forest (49\%) and a permeable matrix that decreases isolation between fragments. In a situation such as that at Ibiúna, where the agricultural matrix is not permeable to movement of leaf-litter lizards, continuous areas will be necessary for the preservation of the complete lizard community.

The absence of a relationship between fragment size and lizard species richness may be related to the capacity of these leaf-litter species to live in secondary or disturbed forest sites. Alternatively, these species, which have small body sizes (Dixo \& Verdade, 2006), may have low mobility and small area requirements, enabling them to survive in fragments of different sizes, including the small fragments of $<5.5$ ha surveyed at Ibiúna.

The matrix of Ibiúna is a hostile environment to leaflitter lizards (Dixo, 2005) and one would expect corridors linking forest fragments to favour an increase in the richness and abundance of lizards through movement between fragments (Meffe \& Carrol, 1997; Rosemberg et al., 1997). Several studies show that herpetofauna are able to use riparian forests (Burbrink et al., 1998; Maisonneuve \& Rioux, 2001). However, the presence of corridors did not influence species richness, total abundance or abundance of E. gaudichaudii in the Ibiúna landscape, as 
has been observed in Australia (Driscol, 2004). The lack of influence of corridors is probably related to the absence of an effect of fragment size. The leaf-litter lizards of the fragments that we studied at Ibiúna are therefore functionally isolated (Trakhtenbrot et al., 2005).

In conclusion, the effects of forest fragmentation in Ibiúna on the two dominant sympatric lizard species E. perditus and E. gaudichaudii are influenced by differences in their microhabitat use, and E. perditus could be a good indicator of disturbance. In addition, the conservation of this assemblage of leaf-litter lizards will depend, at a regional scale, on the maintenance of large tracts of continuous forest because neither the size of fragments nor the presence of connections that could favour regional (metapopulation) dynamics seemingly influence lizard occurrence. Strategies for conservation of leaf-litter lizards in such highly fragmented Atlantic Forest landscapes will need to consider greater connectivity between fragments and continuous forest, allowing the latter areas to act as sources of individuals for fragments.

\section{Acknowledgements}

We are grateful to Henning Steinicke, Guarino R. Colli, Marcio Martins, Ricardo J. Sawaya, Ana Carolina O.Q. Carnaval and two anonymous reviewers for helpful comments, to Miguel T. Rodrigues for identifying lizards, Jose Mario B. Ghellere, Marcelo Awade, Maria Cristina Peruzin, Ricardo Braga-Neto and Sergio Marques de Sousa for help in the field, José Roberto Nali and SABESP for facilitating our research at the Morro Grande Reserve, and the many landowners who authorized access to their properties. This work was carried out with permits for herpetofauna capture and collection from the Instituto Brasileiro do Meio Ambiente e Recursos Naturais Renováveis. Funding was provided by the Fundação de Amparo a Pesquisa do Estado de São Paulo, Brazilian Council for Research and Technology (CNPq), German Federal Ministry of Education and Research (BMBF) and Fundação O Boticário de Proteção à Natureza.

\section{References}

Araújo, M.B., Thuiller, W. \& Pearson, R.G. (2006) Climate warming and the decline of amphibians and reptiles in Europe. Journal of Biogeography, 33, 1712-1728.

Bell, K.E. \& Donnelly, M.A. (2006) Influence of forest fragmentation on community structure of frogs and lizards in northeastern Costa Rica. Conservation Biology, 20, 1750-1760.

Brown, G.W. \& Nelson, J.L. (1993) Influence of successional stage of Eucalyptus regnans (mountain ash) on habitat use by reptiles in the central highlands, Victoria. Australian Journal of Ecology, $18,405-417$.

Brown, S. \& Lugo, A.E. (1990) Tropical secondary forests. Journal of Tropical Ecology, 6, 1-32.
Burbrink, F.T., Phillips, C.A. \& Heske, E.J. (1998) A riparian zone in southern Illinois as a potential dispersal corridor for reptiles and amphibians. Biological Conservation, 86, 107-115.

Catharino, E.L., Bernacci, L.C., Franco, G.A.D.C., Durigan, G. \& MetzGer, J.P. (2006) Aspectos da composição e diversidade do componente arbóreo das florestas da Reserva Florestal do Morro Grande, Cotia, SP. Biota Neotropica, 6(2). Http://www.biotaneotropica.org.br/v6n2/pt/fullpaper? bno0306022006+pt [accessed 25 May 2006].

Cechin, S.Z. \& Martins, M. (2000) Eficiência de armadilhas de queda (pitfall traps) em amostragens de anfíbios e répteis no Brasil. Revista Brasileira de Zoologia, 17, 729-740.

Colwell, R.K. (1997) EstimateS: Statistical Estimation of Species Richness and Shared Species from Samples, v. 5. Http://viceroy.eeb.uconn.edu/estimates [accessed 26 May 2006].

Corn, P.S. (1994) Standard techniques for inventory and monitoring-straight-line drift fences and pitfall traps. In Measuring and Monitoring Biological Diversity. Standard Methods for Amphibians (eds W.R. Heyer, M.A. Donnelly, R.W. McDiarmid, L.C. Hayek \& M.S. Foster), pp. 118-124. Smithsonian Institution Press, Washington, DC, USA.

Cosson, J.F., Ringuet, S., Claessens, O., De Massary, J.C., Dalecky, A., Villiers, J.F. et al. (1999) Ecological changes in recent land-bridge islands in French Guiana, with emphasis on vertebrate communities. Biological Conservation, 91, 213-222.

De Walt, S.J., Maliakal, S.K. \& Denslow, J.S. (2003) Changes in vegetation structure and composition along a tropical forest chronosequence: implications for wildlife. Forest Ecology and Management, 182, 139-151.

DiскмаN, C.R. (1987) Habitat fragmentation and vertebrate species richness in an urban environment. Journal of Applied Ecology, $24,337-351$.

Dixo, M. (2001) Efeito da fragmentação da floresta sobre a comunidade de sapos e lagartos de serrapilheira no sul da Bahia. MSc thesis, University of São Paulo, São Paulo, Brazil.

Dixo, M. (2005) Diversidade de sapos e lagartos de serrapilheira numa paisagem fragmentada do Planalto Atlântico de São Paulo. $\mathrm{PhD}$ thesis, University of São Paulo, São Paulo, Brazil.

Dixo, M. \& Martins, M. (2008) Are leaf-litter frogs and lizards affected by edge effects due to forest fragmentation in Brazilian Atlantic forest? Journal of Tropical Ecology, 24, 551-554.

Dixo, M. \& VERDADE, V.K. (2006) Herpetofauna de serrapilheira da Reserva Biológica de Morro Grande, Cotia (SP). Biota Neotropica, 6(2). http://www.biotaneotropica.org.br/v6n2/pt/fullpaper? bnoo806022006+pt [accessed 25 May 2006].

Driscol, D.A. (2004) Extinction and outbreaks accompany fragmentation of a reptile community. Ecological Applications, 14, 220-240.

FAHRIG, L. (2003) Effects of habitat fragmentation on biodiversity. Annual Reviews in Ecology, Evolution and Systematics, 34, 487-515.

Faria, D., Paciencia, M.L.B., Dixo, M., Laps, R.R. \& BAumgarten, J. (2007) Ferns, frogs, lizards, birds and bats in forest fragments and shaded cacao plantations of two contrasting landscapes in the Atlantic forest, Brazil. Biodiversity and Conservation, 16, 2335-2357.

Freire, M.E.X. (2001) Composição, taxonomia, diversidade e considerações zoogeográficas sobre a fauna de lagartos e serpentes de remanescentes da Mata Atlântica do estado de Alagoas, Brasil. $\mathrm{PhD}$ thesis, Museu Nacional, Rio de Janeiro, Brazil.

Gascon, C., Lovejoy, T.E., Bierregaard, R.O., Malcolm, J.R., S touffer, P.C., Vasconcelos, H. et al. (1999) Matrix habitat and species persistence in tropical forest remnants. Biological Conservation, 91, 223-229. 
Gibions, J.W., Scott, D.E., Ryan, T.J., Buhlmann, K.A., Tuberville, T.D., Metts, B.S. et al. (2000) The global decline of reptiles, déjà vu amphibians. BioScience, 50, 653-666.

JACKSON, J.F. (1978) Differentiation in the genera Enyalius and Strobilurus (Iguanidae): implications for Pleistocene climatic changes in eastern Brazil. Arquivos de Zoologia (São Paulo), $30,1-79$.

Jellinek, S., Driscol, D.A. \& Kirkpatrik, J.B. (2004) Environmental and vegetation variables have a greater influence than habitat fragmentation in structuring lizard communities in remnant urban bushland. Austral Ecology, 29, 294-304.

Kichener, D.J., Chapman, A.D., Dell, J. \& Muir, B.G. (1980) Lizard assemblage and reserve size and structure in the Western Australian wheatbelt-some implications for conservation. Biological Conservation, 17, 25-62.

Köppen, W. (1948) Climatologia. Fondo Cultura Economica, México City, México.

Liou, N.S. (2008) História Natural de duas espécies simpátricas de Enyalius (Squamata, Leiosauridae) na Mata Atlântica do sudeste brasileiro. MSc thesis, University of São Paulo, São Paulo, Brazil.

Maisonneuve, C. \& Rioux, S. (2001) Importance of riparian habitats for small mammal and herpetofauna communities in agricultural landscapes of southern Québec. Agriculture, Ecosystem and Environment, 83, 165-175.

Malcolm, J.R. (1995) Forest structure and the abundance and diversity of Neotropical small mammals. In Forest Canopies (eds M.D. Lowman \& N.M. Nadkarni), pp. 179-197. Academic Press, San Diego, USA.

Malcolm, J.R. \& RAY, J.C. (2000) Influence of timber extraction routes on Central African small-mammal communities, forest structure, and tree diversity. Conservation Biology, 14, 1623-1638.

Marques, O.A.V. \& Sazima, I. (2004) História natural dos répteis da estação ecológica Juréia-Itatins. In Estação Juréia-Itatins: ambiente físico, flora e fauna (eds O.A.V. Marques \& V. Duleba), pp. 257-277. Holos Press, Ribeirão Preto, Brazil.

McCune, B. \& Mefford, M.J. (1999) Pc-Ord for Windows: Multivariate Analysis of Ecological Data, v. 4.25. MjM Software, Oregon, USA.

McGarigal, K. \& Cushman, S.A. (2002) Comparative evaluation of experimental approaches to the study of habitat fragmentation effects. Ecological Applications, 12, 335-345.

McGarigal, K. \& Marks, B.J. (1995) FRAGSTAT: Spatial Pattern Analysis Program for Quantifying Landscape Structure. US Forest Service General Technical Report PNW 351. US Forest Service, Portland, USA.

Meffe, G.K. \& Carrol, C.R. (1997) Principles of Conservation Biology, 2nd ed. Sinauer Associates, Sunderland, USA.

Metzger, J.P., Alves, L.F., Goulart, W., Teixeira, A.M.G., Simões, S.J.C. \& Catharino, E.L.M. (2006) Uma área de relevante interesse biológico, porém pouco conhecida: a Reserva Florestal do Morro Grande. Biota Neotropica, 6(2). Http://www.biotaneotropica.org.br/v6n2/pt/abstract?article+ bno0206022006 [accessed 25 May 2006].

Myers, N., Mittermeier, R.A., Mittermeier, G.G., Fonseca, G.A.B. \& KENT, J. (2000) Biodiversity hotspots for conservation priorities. Nature, 403, 853-858.

Oliveira-Filho, A.T. \& Fontes, M.A.L. (2000) Patterns of floristic differentiation among Atlantic Forests in southeastern Brazil and influence of climate. Biotropica, 32, 793-810.

Pardini, R., Accacio, G.M., Laps, R.R., Mariano, E., PacienCiA, M.L.B., Dixo, M. et al. (2009) The challenge of maintaining Atlantic forest biodiversity: a multi-taxa conservation assessment of specialist and generalist species in an agro- forestry mosaic in southern Bahia. Biological Conservation, 142, $1170-1182$.

Pardini, R., Souza, S.M., Braga-Neto, R. \& Metzger, J.P. (2005) The role of forest structure, fragment size and corridors in maintaining small mammal abundance and diversity in an Atlantic forest landscape. Biological Conservation, 124, 253-266.

Pough, F.H., Andrews, R.M., Cadle, J.E., Crump, M.L., Savitzky, A.H. \& Wells, K.D. (1998) Herpetology. Prentice Hall, Upper Saddle River, USA.

Ribeiro, M.C., Metzger, J.P., Martensen, A.C., Ponzoni, F.J. \& Hirota, M.M. (2009) The Brazilian Atlantic Forest: how much is left, and how is the remaining forest distributed? Implications for conservation. Biological Conservation, 142, 1144-1156.

Rodrigues, M.T. (2005) The conservation of Brazilian reptiles: challenges for a megadiverse country. Conservation Biology, 19, 659-664.

RosemberG, D.K., Noon, B.R. \& Meslow, E.C. (1997) Biological corridors: form, function and efficacy. BioScience, 47, 677-687.

Sarre, S., Smith, G.T. \& Meyers, J.A. (1995) Persistence of two species of gecko (Oedura reticulata and Gehyra variegata) in remnant habitat. Biological Conservation, 71, 25-33.

SAZIMA, I. (2001) Répteis. In Intervales / Fundação para a conservação e produção florestal do estado de São Paulo (ed. C. Leonel), pp. 148-158. A Fundação Florestal, São Paulo, Brazil.

SAZima, I. \& Haddad, C.F.B. (1992) Répteis da Serra do Japi: notas sobre história natural. In História Natural da Serra do Japi. Ecologia e preservação de uma área florestal no sudeste do Brasil (ed. P. Morellato), pp. 212-235. UNICAMP/FAPESP, Campinas, Brazil.

Silva, W.G.S., Metzger, J.P., Simões, S. \& Simonetti, C. (2007) Relief influence on the spatial distribution of the Atlantic Forest cover at the Ibiúna Plateau, SP. Brazilian Journal of Biology, 67, 631-640.

Silvano, D., Colli, G., Dixo, M., Pimenta, B. \& WiederHeCKer, H.C. (2003) Anfíbios e répteis. In Fragmentação de Ecossistemas: causas, efeitos sobre a biodiversidade e recomendações de políticas públicas (eds D.M. Rambaldi \& D.A.S. Oliveira), pp. 183-200. MMA/SBF, Brasília, Brazil.

Smith, G.T., Arnold, G.W., Sarre, S., Abenperg-Traun, M. \& SteVen, D.E. (1996) The effects of habitat fragmentation and livestock grazing on animal communities in remnants of gimlet Eucalyptus salubris woodland in the Western Australian wheatbelt. II. Lizards. Journal of Applied Ecology, 33, 1302-1310.

SOS Mata Atlântica \& Instituto Nacional de Pesquisas Espaciais (2008) Atlas dos remanescentes florestais da Mata Atlântica, período de 2000 a 2005. Http://www.sosmatatlantica.org.br [accessed 25 October 2008].

Seabra, M. (1971) Vargem Grande: Organização e Transformação de um Setor do Cinturão Paulistano. Instituto de Geografia, USP, São Paulo, Brazil.

Statsoft Inc. (2001) STATISTICA (Data Analysis Software System), v. 6. Http://www.statsoft.com/ [accessed 26 May 2006].

Sumner, J., Moritz, C. \& Shine, R. (1999) Shrinking forest shrinks skink: morphological change in response to rainforest fragmentation in the prickly forest skink (Gnypetoscincus queenslandiae). Biological Conservation, 91, 159-167.

Teixeira, A.M.G., Soares-Filho, B.S., Freitas, S.R. \& Metzger, J.P. (2009) Modeling landscape dynamics in an Atlantic Rainforest region: implications for conservation. Forest Ecology and Management, 257, 1219-1230.

Ter Braak, C.J.F. \& Smilauer, P. (1998) CANOCO for Windows, v. 4.o. Center for Biometry Wageningen CPRO-DLO, Wageningen, The Netherlands. 
Trakhtenbrot, A.R., Nathan, R., Perry, G. \& Richardson, D.M. (2005) The importance of long-distance dispersal in biodiversity conservation. Diversity and Distributions, 11, 173-181.

Whitfield, S.M. \& Donnelly, M.A. (2006) Ontogenetic and seasonal variation in the diet of a Costa Rican leaflitter herpetofauna. Journal of Tropical Ecology, 22, 409-417.

Zimmerman, G.M., Goetz, H. \& Mielke, Jr, P.W. (1985) Use of an improved statistical method for group comparisons to study effects on prairie fire. Ecology, 66, 606-611.

\section{Biographical sketches}

Marianna Dixo has been involved in conservation biology and biodiversity research on amphibians and reptiles since 1999. Her current research focus is the diversity of leaf herpetofauna in three fragmented landscapes of the Brazilian Atlantic forest with different amounts of remaining habitat, investigating the importance of fragment size and connectivity for the conservation of leaf-litter herpetofauna. Jean Paul Metzger carries out research on the biological effects of forest fragmentation and connectivity, particularly in the Brazilian Atlantic rainforest. 